\title{
Bothriocephalidean tapeworms (Cestoda) from the blackfish, Centrolophus niger (Perciformes: Centrolophidae)
}

\author{
Roman Kuchta $^{1,2}$, Tomáš Scholz ${ }^{2}$, Jan Brabec ${ }^{1,2}$, Dagmar Jirsová ${ }^{1}$ and Andrea Gustinelli ${ }^{3}$ \\ ${ }^{1}$ Faculty of Science, University of South Bohemia and ${ }^{2}$ Institute of Parasitology, Biology Centre of the Academy of Sciences of \\ the Czech Republic, České Budějovice, Czech Republic; \\ ${ }^{3}$ Department of Public Veterinary Health and Animal Pathology, University of Bologna, Italy
}

Key words: Bothriocephalidea, species survey, Amphicotyle heteropleura, Bothriocotyle solinosomum, Echinophallus wageneri, Milanella familiaris, morphology, taxonomy, identification key

\begin{abstract}
Bothriocephalidean tapeworms parasitic in the blackfish, Centrolophus niger (Gmelin) (Perciformes: Centrolophidae), are redescribed on the basis of the evaluation of freshly collected specimens and museum material. This evaluation enabled us to supplement species diagnoses by new morphological characters of potential use for phylogenetic analyses, including the data from scanning electron microscopical observations, and to provide a key to identification of the following four species occurring in this fish: Amphicotyle heteropleura (Diesing, 1850); Milanella familiaris Kuchta et Scholz, 2008 (both Triaenophoridae); Bothriocotyle solinosomum Ariola, 1900; and Echinophallus wageneri (Monticelli, 1890) (both Echinophallidae). Large spiniform microtriches were observed on the surface of the posterodorsal margin of segments of B. solinosomum, E. wageneri and M. familiaris. The invalidity of Atelemerus Guiart, 1935, first proposed by Bray et al. (1994), is supported by the present data and its type species, A. acanthodes Guiart, 1935, is newly synonymised with E. wageneri.
\end{abstract}

Tapeworms of the order Bothriocephalidea Kuchta, Scholz, Brabec et Bray, 2008 (see Kuchta et al. 2008) are common parasites mostly of marine fishes. Seven taxa have been described from the blackfish, Centrolophus niger (Gmelin) (Perciformes: Centrolophidae), namely Amphicotyle heteropleura (Diesing, 1850); A. typica Diesing, 1863; Milanella familiaris Kuchta et Scholz, 2008 (all placed in the Triaenophoridae); Atelemerus acanthodes Guiart, 1935; Bothriocotyle solinosomum Ariola, 1900; Echinophallus wageneri (Monticelli, 1890); and E. settii (Ariola, 1895) (all Echinophallidae). Most of these cestodes were studied by Lühe (1902) and later in more detail by Schumacher (1914), who proposed a new family, Echinophallidae, to accommodate the tapeworms with a sublateral genital pore.

Since that time, almost nothing has been added to the knowledge of these tapeworms, except for an incomplete description of A. acanthodes by Guiart (1935) and recent description of a new taxon, Milanella familiaris, by Kuchta and Scholz (2008). In recent monographs (Protasova 1977, Schmidt 1986, Bray et al. 1994), data on the above-listed cestode species have just been compiled from the papers published at the beginning of the 20th century, mainly that of Schumacher (1914). Although this account was very detailed, it did not provide complete data necessary for current taxonomic and phylogenetic studies; in addition, descriptions were based almost exclusively on cross-sections.

During a research cruise by the first author (R.K.) in the North Atlantic in the autumn of 2004, examination of four blackfish made it possible for him to collect fresh material of cestodes. This material, together with a critical evaluation of numerous voucher specimens from helminthological collections, enables us to provide more details on the morphology of all species recognized here as valid, including characters of potential importance for phylogenetic analyses. Therefore, three species are redescribed herein and the taxonomic status of other taxa reported from this fish host is discussed. A simple identification key based on gross morphology is provided.

\section{MATERIALS AND METHODS}

Tapeworms were found in freshly killed Centrolophus niger (a total of four specimens examined) from the North Atlantic off the western coast of the Outer Hebrides $\left(56^{\circ} 20^{\prime} \mathrm{N}\right.$, $9^{\circ} 12^{\prime} \mathrm{W}$; depth 500-1,000 m) caught during an expedition of the research vessel Scotia of the Fisheries Research Services in August and September 2004. Most tapeworms found were fixed with hot $4 \%$ formaldehyde solution for morphological studies, including scanning electron microscopy (SEM) observations and histology. The specimens for a morphological study were stained with Mayer's hydrochloric carmine and mounted as permanent slides in Canada balsam. Parts of the strobila were also cross-sectioned, using standard histological procedure (Scholz and Hanzelová 1998). Several scoleces and segments were prepared for SEM observations using the methodology outlined by Scholz et al. (1998). Illustrations were made using a drawing attachment on Olympus BX51 microscope with Nomarski interference contrast. Measurements in descriptions are given in micrometres $(\mu \mathrm{m})$ unless otherwise stated. 
Tapeworms found in C. niger from an underwater plateau Chatham Rise $\left(44^{\circ} 29^{\prime} \mathrm{S}, 173^{\circ} 51^{\prime} \mathrm{E}\right.$; depth $758 \mathrm{~m}$; 16.i. 2005), Pacific Ocean off New Zealand, collected by Claire Healy, and those from the Cesenatico $\left(44^{\circ} 12^{\prime} \mathrm{N}, 12^{\circ} 23^{\prime} \mathrm{E}\right.$; depth $20 \mathrm{~m}$; iii. 2005), Adriatic Sea off Italy, collected by Andrea Gustinelli, were also studied. All newly collected material has been deposited in the collections of the Institute of Parasitology, BC, ASCR, České Budějovice (acronym IPCAS), The Natural History Museum, London, UK (BMNH) and Muséum d'Histoire Naturelle, Geneva, Switzerland (MHNG INVE): Amphicotyle heteropleura (IPCAS C-453; BMNH 2008.2.8.59; MHNG INVE 60368), Bothriocotyle solinosomum (IPCAS C-442; BMNH 2008.2.8.10-17; MHNG INVE 60366), Echinophallus wageneri (IPCAS C-443; BMNH 2008.2.8.18-25; MHNG INVE 60362).

Furthermore, voucher specimens from the following museums were studied: The Natural History Museum, London, UK; Muséum d'Histoire Naturelle, Geneva, Switzerland; Naturhistorisches Museum, Berlin, Germany (NHMB); Natural History Museum, National Museum \& Galleries of Wales, UK (NMGW); Naturhistorisches Museum, Wien, Austria (NMW); Muséum National d'Histoire Naturelle, Paris, France (MNHNP).

(1) Amphicotyle heteropleura: one specimen of the type series from Trieste, Italy, collected by Koch (NMW 2600); two specimens from North Sea, Aberdeen, Scotland, UK (BMNH Nos. 1977.1.10.222-227); four specimens from Atlantic Ocean, NW off Outer Hebrides $\left(57^{\circ} 30^{\prime} \mathrm{N}\right.$, $9^{\circ} 38^{\prime} \mathrm{W}$; 12.vi. 1974 and $60^{\circ} 37^{\prime} \mathrm{N}, 8^{\circ} 45^{\prime} \mathrm{W}$; 1.vii. 1976), collected by R.A. Bray (BMNH 1981.1.22.1-29); two specimens from Table Bay, South Africa, R.A. Bray (BMNH 1982.11.10.1-3); two specimens from unknown locality (BMNH 1982.1.19.39 and 1988.10.28.14-17); eight specimens from North Sea, Findhorn and Inverness, Scotland, UK, 1955, H.H. Williams (NMGW Z.1994.027); one specimen from unknown locality (MHNG INVE 27961); two specimens from unknown locality (NHMB 3683); several specimens from the Atlantic coast of France (MNHNP C 91, 95, 96).

(2) Amphicotyle typica: one specimen from unknown locality (NHMB Q.3704).

(3) Atelemerus sp.: one specimen from Table Bay, South Africa, R.A. Bray (BMNH 1982.11.10.4).

(4) Bothriocotyle solinosomum: three specimens from Atlantic Ocean, NW off Outer Hebrides $\left(59^{\circ} 15^{\prime} \mathrm{N}, 7^{\circ} 11^{\prime} \mathrm{W}\right.$; ix. 1978), R.A. Bray (BMNH 1981.1.22.1-29); five specimens from unknown locality (BMNH 1988.10.28.14-17); six specimens from North Sea, Findhorn and Inverness, Scotland, UK, 1955, H.H. Williams (NMGW Z.1994.027); one specimen from Italy (NMW 2628); several specimens from the Atlantic coast of France (MNHNP C 91).

(5) Echinophallus wageneri: two specimens from Aberdeen, Scotland, UK (BMNH 1977.1.10.222-227); one specimen from Atlantic Ocean, NW off Outer Hebrides $\left(59^{\circ} 15^{\prime} \mathrm{N}\right.$, $7^{\circ} 11^{\prime} \mathrm{W}$; ix. 1978), R.A. Bray (BMNH 1981.1.22.1-29); two specimens from unknown locality (BMNH 1982.1.19.39 and 1988.10.28.14-17); 13 specimens from North Sea, Findhorn and Inverness, Scotland, UK, 1955, H.H. Williams (NMGW Z.1994.027); two specimens from Italy (NMW 2627); two specimens from unknown locality (NHMB 1124); crosssections from unknown locality (MHNG INVE 134/5-14); several specimens from the Atlantic coast of France (MNHNP C 91, 96; bD 10/14).

(6) Milanella familiaris: see Kuchta and Scholz (2008).

\section{RESULTS}

The following four species of bothriocephalidean cestodes infecting the blackfish are considered to be valid: (i) Amphicotyle heteropleura (Diesing, 1850); (ii) Milanella familiaris Kuchta et Scholz, 2008 (both Triaenophoridae); (iii) Bothriocotyle solinosomum Ariola, 1900; and (iv) Echinophallus wageneri (Monticelli, 1890) (both Echinophallidae). Three of these taxa are redescribed herein and remarks on their morphology, distribution and phylogenetic relationships are provided, together with an identification key of all four cestode species.

\section{Survey of species}

Amphicotyle heteropleura (Diesing, 1850) Lühe, 1902

Figs. 1-3, 8, 14-18

Synonyms: Dibothrium heteropleurum Diesing, 1850; Amphicotyle typica Diesing, 1863; Bothriocephalus heteropleurus Stossich, 1890.

Description (largely based on histological sections, including measurements of most internal structures; measurements of very large specimens from New Zealand in parentheses). Bothriocephalidea, Triaenophoridae. Large worms, up to $38.5 \mathrm{~cm}$ long and up to $4 \mathrm{~mm}$ wide. Strobila robust, with markedly craspedote (velumlike or pectinate), very short and wide segments; each segment consisting of two pseudosegments, anterior one being slightly larger (Figs. 3, 16). External and secondary segmentation present. Longitudinal osmoregulatory canals numerous. Longitudinal musculature well developed, formed by large bundles of muscle fibres (Fig. 17). In stained preparations, numerous intensely stained corpuscles (diameter $13-24 ; \mathrm{n}=10$ ) present throughout strobila, reaching up to scolex.

Surface covered with small filiform microtriches similar in shape and size.

Scolex oval (Fig. 1) to trapeziform in dorsoventral view, 619-925 (1,820-2,890) long by 245-688 (520 $600)$ wide, sagittate in lateral view, with freely projecting posterior margins in lateral view; apical disc well developed, 180-250 (560-740) wide in dorsoventral direction (Figs. 1, 2). Bothria 480-690 long by $280-500$ wide $(2,220 \times 540)$, elongate, shallow, with spherical, sucker-like depression near posterior margin, 40-210 in diameter (Fig. 1). Neck absent, first segments starting immediately posterior to scolex. 
Kuchta et al.: Tapeworms from Centrolophus niger
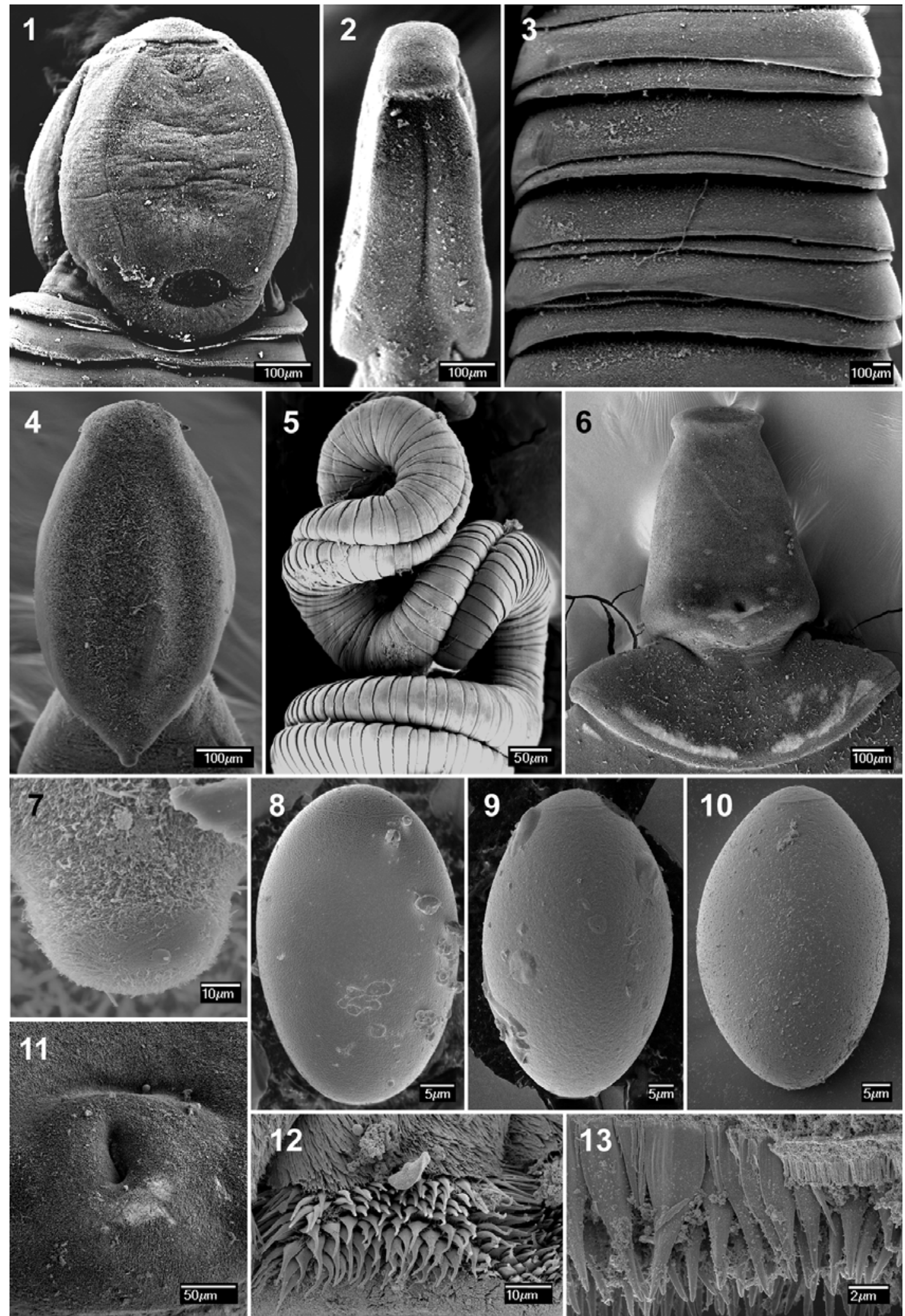

Figs. 1-13. Scanning electron micrographs of cestodes from Centrolophus niger. Figs. 1-3, 8. Amphicotyle heteropleura from Outer Hebrides. Fig. 1. Scolex in dorsoventral view. Fig. 2. Scolex in lateral view. Fig. 3. Immature strobila. Fig. 8. Egg. Figs. 4, 5, 7, 9, 12. Bothriocotyle solinosomum from Outer Hebrides. Fig. 4. Scolex in dorsoventral view. Fig. 5. Strobila. Fig. 7. Detail view of posterior margin of bothria. Fig. 9. Egg. Fig. 12. Detailed view of posterior margin of segment. Figs. 6, 10, 11, 13. Echinophallus wageneri from Outer Hebrides. Fig. 6. Scolex in dorsoventral view. Fig. 10. Egg. Fig. 11. Detailed view of posterior margin of bothria. Fig. 13. Detailed view of posterior margin of segment. 
Immature and mature segments wider than scolex, very short, much wider than long, 65-360 long by 410 1,630 wide $(\mathrm{n}=10)$ (Fig. 3). Gravid segments much wider than long, 63-498 long by $2,800-2,900$ wide $(n=$ 10) (Figs. 14-16).

Testes medullary, 47-96 in diameter $(n=15)$, in $2-3$ layers, forming large field continuous between segments (Figs. 14, 16). Cirrus-sac large, pyriform, thick-walled, thickest distally (thickness of sac wall up to 32) (Figs. $15,17)$, about 860 long by 470 wide; cirrus-sac representing about $15 \%$ of width of gravid segments. External sperm ducts (vas deferens) forming numerous transversal loops, median to cirrus-sac; internal sperm duct narrow, thick-walled, sinuous; cirrus unarmed, with tegumental invaginations (folds), opening into narrow genital atrium (Fig. 15). Genital pore lateral, alternating irregularly (Fig. 14).

Ovary irregularly shaped, lobulated, in dorsal medulla, with lobes intruding among muscle bundles of inner longitudinal musculature (Fig. 18). Vagina tubular, thick-walled distally, without sphincter. Vitelline follicles circumcortical, including posterior velum-like processes of segments, $31-43$ in diameter $(n=10)$ (Figs. 14, 15, 17).

Uterine sac median, thin-walled, transversely oval, occupying large part of gravid segments (Fig. 14). Uterine pore not observed. Eggs operculate, unembryonated, surface markedly rugose, 35-41 long by 20-22 wide (n $=20)$ (Fig. 8).

Type and only host: Centrolophus niger.

Site of infection: Scolex in pyloric caeca, strobila in the anterior part of the intestine.

T y p e 1 o c a 1 i t y: Adriatic Sea off Trieste, Italy (Mediterranean Sea)

D i s t r i b u t i o n : Atlantic Ocean (Outer Hebrides, France, South Africa); Mediterranean Sea (Venice, Padua, Naples); North Sea (Scotland); Pacific Ocean (New Zealand).

Remarks. The species was briefly described by Diesing (1850) as Dibothrium heteropleurum on the basis of two worms from Centrolophus pompilius (now C. niger) from the Adriatic Sea off Trieste in Italy, collected by Koch (one specimen is still deposited in NMW 2600). The same author (Diesing 1863) proposed a new genus Amphicotyle, to accommodate Amphicotyle typica, another species from the blackfish from the same locality. However, Lühe (1902) synonymised this species with $D$. heteropleurum, which was transferred to Amphicotyle as A. heteropleura and became the type species of this genus (Lühe 1902). Schumacher (1914) provided the most comprehensive account of the morphology of $A$. heteropleura, based on histological sections of specimens from the type locality.

The internal morphology of $A$. heteropleura is almost impossible to observe in stained specimens mounted as permanent preparations, because the strobila is very thick, with strong longitudinal musculature and is formed by very short and wide segments, most of them being immature. Therefore, histological sections are necessary for morphological studies. Using SEM for the first time, the eggs of the tapeworm were found to possess a feebly developed, but distinct operculum (Fig. 8).

Specimens from New Zealand were found to be conspecific because of the identical strobilar morphology (data not shown). Their conspecificity with $A$. heteropleura from the Atlantic Ocean was also confirmed by the almost identical sequences of three genes (cox1, ITS-2, and 28S rRNA - see Kuchta and Scholz 2008).

Bray et al. (1994) provided an illustration (fig. 10.66) of a mature segment of a tapeworm designated as $A$. heteropleura, but it actually belonged to Milanella familiaris (see Kuchta and Scholz 2008). Similarly, Brabec et al. (2006) misidentified the latter cestode as $A$. heteropleura.

\section{Bothriocotyle solinosomum Ariola, 1900} Figs. 4, 5, 7, 9, 12, 19-23

Synonyms: Dibothrium aus Centrolophus pompilius Wagener, 1854; Dibothrium centrolophi pompilii Diesing, 1863; Bothriocotyle solenosomum Ariola, 1900 - misspelled by Lühe (1902) and Schumacher (1914).

Description. Bothriocephalidea, Echinophallidae. Large worms, up to $40 \mathrm{~cm}$ long, with maximum width 4 $\mathrm{mm}$. Strobila folded along longitudinal axis (convex dorsally and concave ventrally) and spiralled (observed also in live material) (Fig. 5). External and internal segmentation present, secondary segmentation present in first immature segments; segments craspedote. Osmoregulatory system well developed, with several pairs of longitudinal canals about 15-30 wide, connected by numerous anastomoses. Longitudinal musculature well developed, formed by numerous bundles of muscle fibres (Fig. 22). Numerous intensely stained corpuscles present throughout strobila (Fig. 21), 12-17 in diameter $(\mathrm{n}=10)$, reaching to scolex, less numerous and transparent in posterior part of strobila.

Surface covered with small filiform microtriches similar in shape and size; posterolateral margins of dorsal side of segments covered with narrow band of large spiniform microtriches, about 15 long (Fig. 12), reaching slightly onto ventral side.

Scolex relatively small, ovoid in dorsoventral view (Fig. 4), slender, arrow-shaped in lateral view, 6501,225 long by $350-850$ wide dorsoventrally (width of scolex in lateral view $320-1,020)(\mathrm{n}=10)$, with posterior, nipple-like projection (Figs. 4, 7), 63-171 long by 86-130 wide, and small, narrow slit-like depression at its extremity. Apical disc weakly developed. Bothria shallow, elongate to ovoid (Fig. 4). Neck absent; first segments starting immediately posterior to scolex.

Immature segments trapeziform, more or less long as wide, becoming soon wider than long, 230-500 long by 530-3,860 wide $(\mathrm{n}=15)$. Mature segments much wider than long, 405-695 long by $1,980-3,920$ wide $(n=15)$. Gravid segments wider than long, 550-1,160 long by 

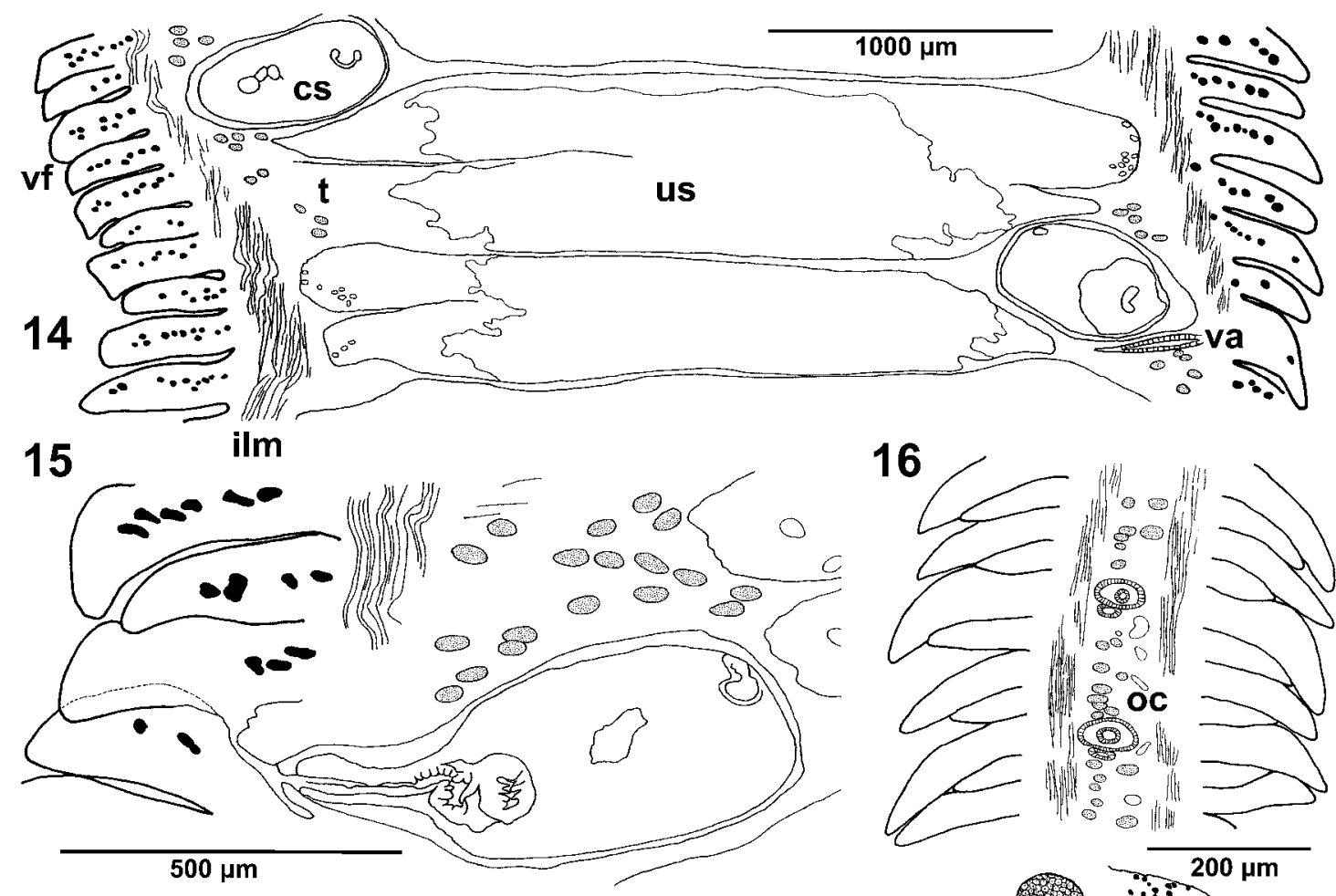

16
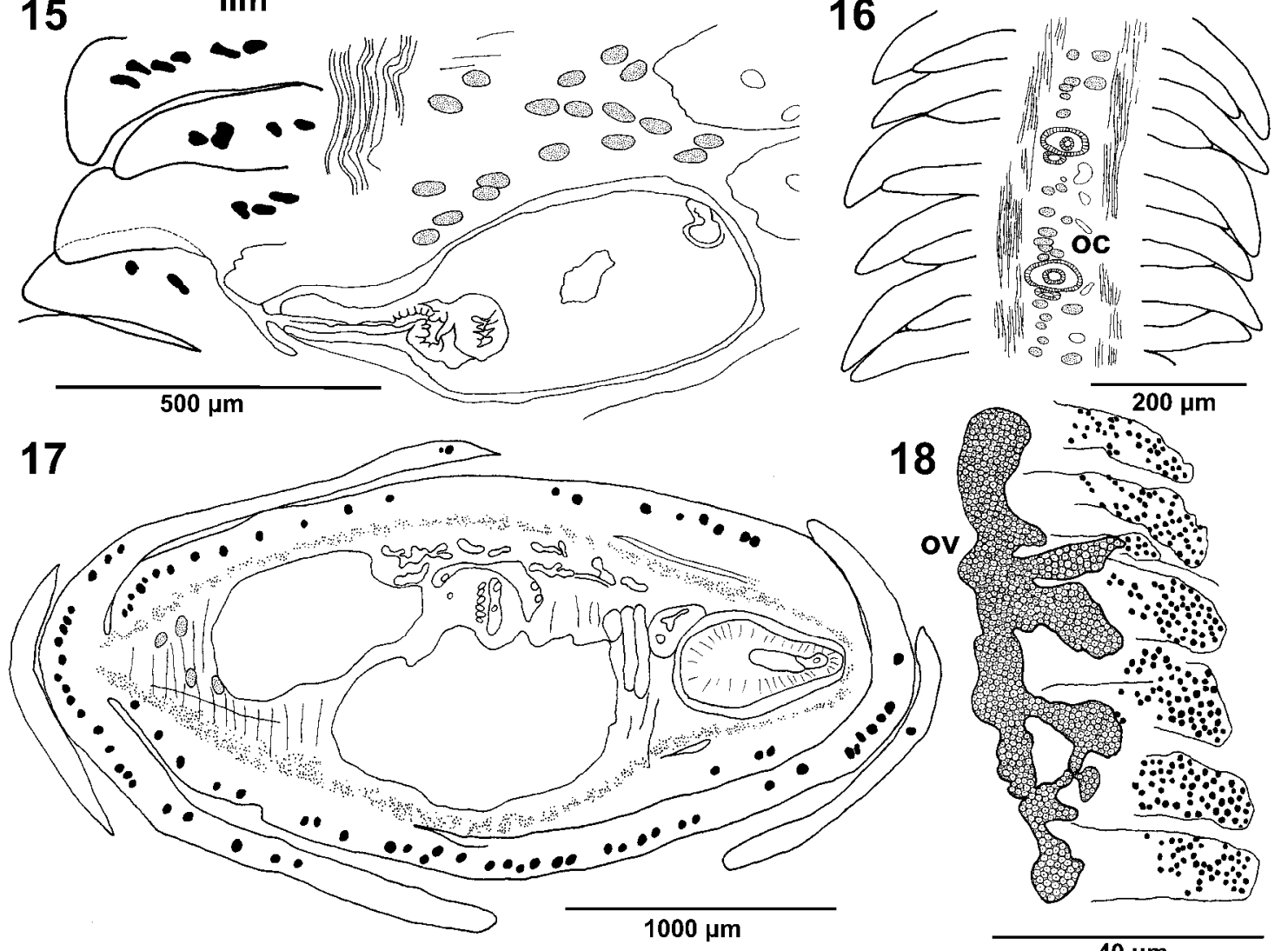

Figs. 14-18. Amphicotyle heteropleura from Italy; histological sections of strobila; eggs in uterine sac not illustrated. Figs. 14, 15. Longitudinal section; dorsoventral view. Fig. 16. Sagittal section; vitellaria not illustrated. Figs. 17, 18. Cross-section at the level of cirrus-sac and ovary, respectively. Abbreviations: cs - cirrus-sac; ilm - inner longitudinal muscles; oc - osmoregulatory canal; ov - ovary; $\mathrm{t}$ - testes; us - uterine sac; va - vagina; $\mathrm{vf}$ - vitelline follicles.

2,520-4,090 wide $(\mathrm{n}=15)$ (Fig. 19), with last segments becoming square or even longer than wide.

Testes medullary, oval, 49-72 in number per segments $(n=10), 50-74$ in diameter $(n=20)$, in two lateral fields, confluent medially near posterior margins, continuous between segments (Fig. 19). Cirrus-sac cylindrical, 420-500 long by $130-175$ wide $(\mathrm{n}=15)$, length representing $8-18 \%$ of width of mature segment $(\mathrm{n}=32)$; proximal (median) part of cirrus-sac angled anteromedially (Figs. 19-21). Musculature of cirrus-sac well developed; cirrus-sac with very thick wall (Fig. 21), especially distally; outer longitudinal layer 19-42 thick and inner circular layer 17-27 thick; proximal part of cirrus-sac surrounded by numerous gland cells (Fig. 21). External sperm duct forming numerous loops, anteromedian to cirrus-sac. Internal sperm duct coiled; cirrus massive, armed with large spines (Fig. 23) about 3 long, opening into small, narrow genital atrium (Fig. 21). Genital atrium dorsal, sublateral, 271-816 from lateral margin, alternating irregularly, equatorial to postequatorial, at 45-73\% of segment length (Fig. 19).

Ovary bilobed, asymmetrical, poral, posteromedian to cirrus-sac, follicular, 98-198 long by 608-913 wide $(\mathrm{n}=15)$ (Figs. 19-22). Vagina tubular, thin-walled, 
crossing ovary dorsally, then bent laterally, with proximal part $22-35$ in diameter $(\mathrm{n}=10)$, and thick-walled markedly distended distal part, 200-247 long by 45-70 wide $(n=15)$, armed with microtriches in proximal part of distended terminal portion, opening into small genital atrium posterior to cirrus-sac (Fig. 21). Vitelline follicles medullary, oval, relatively large (26-55 in diameter; $\mathrm{n}=20$ ), numerous, circumsegmental, absent in medioventral region around uterus (Fig. 19).

Uterine duct winding, forming small, thin-walled loops, filled with eggs and enlarging in gravid segments (Figs. 19, 20). Uterine sac median, oval, occupying anterior part of segments (Fig. 20). Uterine pore median, opening ventrally. Eggs oval, operculate, unembryonated, with slightly pitted surface (Fig. 9), 56-65 long by $40-20$ wide $(\mathrm{n}=20)$.

Type and only host: Centrolophus niger.

$\mathrm{S}$ it e of infection: Scolex in pyloric caeca, strobila in the anterior part of the intestine.

T y p e 1 o c a 1 i t y : Ligurian Sea off Genoa, Italy (Mediterranean Sea)

D i s t r i b u t i o n : Atlantic Ocean (Outer Hebrides, France, South Africa); Mediterranean Sea (Genoa, Venice, Padua, Naples); North Sea (Scotland); Pacific Ocean (New Zealand).

Remarks. Ariola (1900a) described Bothriocotyle solinosomum as a new species of a new genus on the basis of the material collected by C. Parona and himself in Genoa. He considered Wagener's (1854) tapeworms designated as Dibothrium aus Centrolophus pompilius to be a synonym of B. solinosomum. Yamaguti (1959) transferred the genus from the family Echinophallidae to the Amphicotylidae (now considered to be a synonym of the Triaenophoridae - Bray et al. 1994, Kuchta et al. 2008) and proposed a new subfamily Bothriocotylinae, but did not justify its erection. Subsequent authors placed the genus back in the Echinophallidae (Protasova 1977, Schmidt 1986, Bray et al. 1994, Kuchta et al. 2008), with which we concur. Bothriocotyle solinosomum is the type and only species of Bothriocotyle.

Our observations correspond more or less to the literary data (Schumacher 1914), but the following slight differences were observed: (i) the inner longitudinal musculature, described to be more developed ventrally than on the dorsal side, is in fact identical on both sides (Fig. 22); (ii) the actual number of testes is slightly lower (at maximum 72 in a segment) than that reported by Schumacher (1914 - about 90); (iii) the proximal (basal) part of the terminal extended portion of the vagina is covered with fine microtriches (Fig. 21), which has not been mentioned previously; (iv) using SEM for the first time, the eggs of the tapeworm were found to possess a feebly developed, but distinct operculum (Fig. 9). All previous authors reported the eggs to be unoperculated (Schumacher 1914, Yamaguti 1959, Protasova 1977, Schmidt 1986, Bray et al. 1994).
Echinophallus wageneri (Monticelli, 1890) Schumacher, 1914

Figs. 6, 10, 11, 13, 24-27

Synonyms: Bothriocephalus wageneri Monticelli, 1890; Diplogonoporus wageneri Ariola, 1895; Diplogonoporus settii Ariola, 1895 new synonym; Amphitretus wageneri Lühe, 1902 preoccupied; Acanthocephallus wageneri Lühe, 1910 preoccupied; Atelemerus acanthoides Guiart, 1935 new synonym.

Description. Bothriocephalidea, Echinophallidae. Large, very wide worms, up to $50 \mathrm{~cm}$ long and $2 \mathrm{~cm}$ wide. Strobila flat, folded along longitudinal axis (convex dorsally and concave ventrally) also in live specimens within fish host. External and internal segmentation present, secondary segmentation present; each segment formed by two pseudosegments, each containing two proglottides, i.e. parallel sets of genitalia (Fig. 24). Segments markedly craspedote, much wider than long, with frilled (tongue-shaped) posterior margins on ventral side. Osmoregulatory system well developed, with several pairs of longitudinal canals; dorsal canals narrower, connected by many transverse anastomoses. Longitudinal musculature well developed, formed by numerous bundles of muscle fibres (Fig. 27). Numerous intensely stained corpuscles (diameter $18-26 ; n=10$ ) present throughout strobila (Fig. 26).

Surface covered with small filiform microtriches similar in shape and size; posterolateral margins of dorsal side of pseudosegments covered with narrow band of large spiniform microtriches, up to 20 long (Fig. 13), reaching slightly onto ventral side.

Scolex pyramidal to trapeziform, narrower than first segment, 690-1,470 long by 610-1,260 wide (in dorsoventral direction); 740-1,000 wide in lateral direction $(\mathrm{n}=7)$, with slightly developed apical disc, 250415 in dorsoventral diameter and 255-375 in lateral diameter. Bothria weakly developed, very shallow, with slit-like incision near posterior extremity (Figs. 6, 11). Neck absent, first segment starting immediately posterior to scolex.

Immature segments $420-630$ long by $1.7-11.9 \mathrm{~mm}$ wide $(\mathrm{n}=10)$. Mature segments $450-630$ long by $10.5-$ $20 \mathrm{~mm}$ wide $(\mathrm{n}=10)$. Gravid segments more slender, $630-840$ long by $7.2-8.6 \mathrm{~mm}$ wide $(\mathrm{n}=10)$ (Fig. 24$)$, slightly deformed near end of strobila.

Testes medullary, oval, $70-82$ in diameter $(n=20)$, exclusively on ventral side of medulla, estimated to be about 200 per segment; testes forming narrow, transverse bands along anterior and posterior margins of segments between genital pores; fields in each other pseudosegment confluent medially (Fig. 24).

Cirrus-sac large, elongate to cylindrical, with proximal part angled anteromedially and thick-walled distal part (outer longitudinal layer 30-62 thick and inner circular layer 14-24 thick), opening into small, narrow genital atrium (Fig. 26). Cirrus-sac 345-710 long by $95-160$ wide $(\mathrm{n}=20)$, representing $4-8 \%$ of width of 

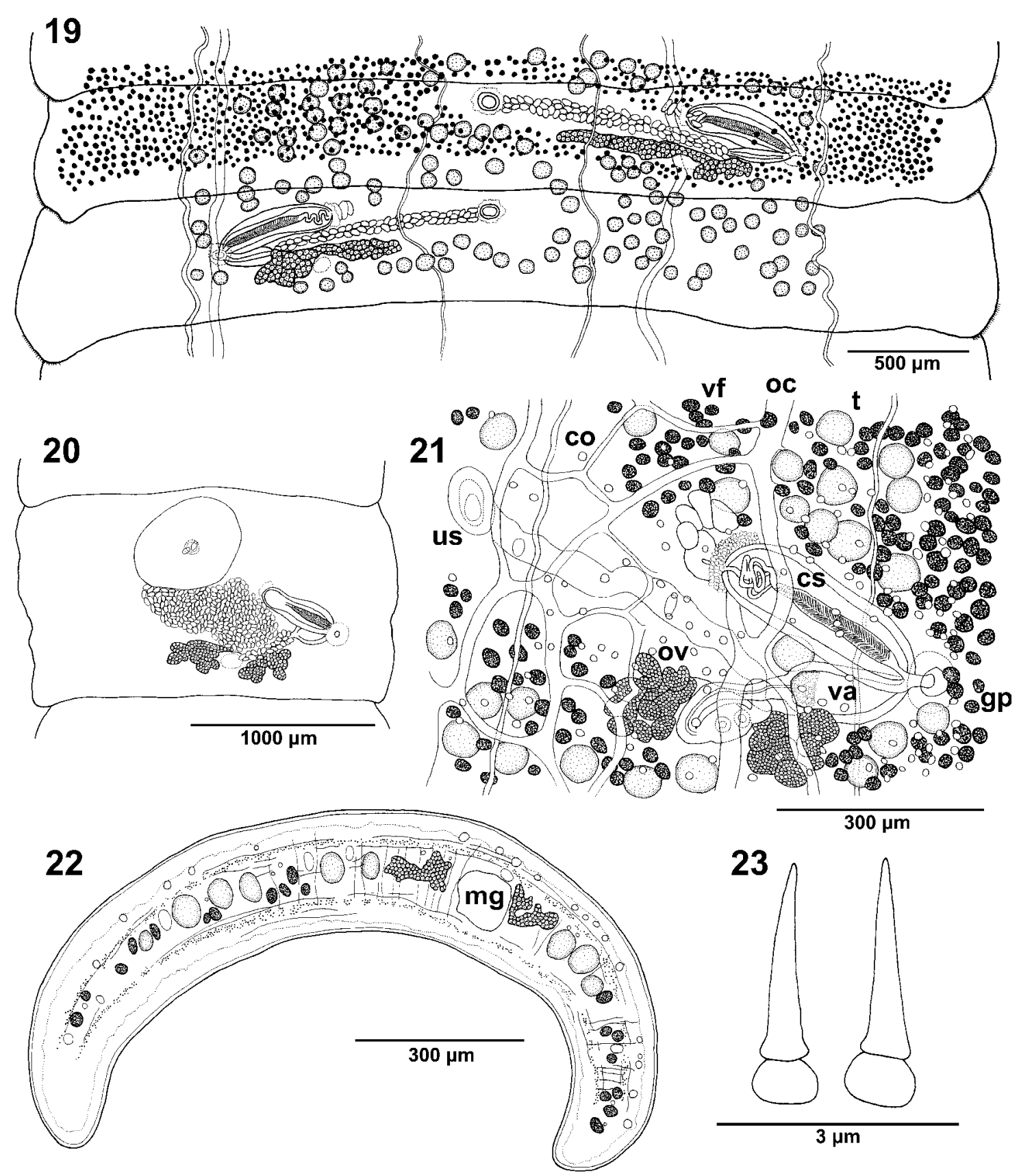

Figs. 19-23. Bothriocotyle solinosomum from Outer Hebrides. Fig. 19. First gravid segments; ventral view. Fig. 20. Schematic drawing of gravid segments; dorsal view; eggs in uterine sac, testes and vitellaria not illustrated. Fig. 21. Terminal genitalia; ventral view. Fig. 22. Cross-section of segment at the level of ovary. Fig. 23. Detail of cirrus spines. Abbreviations: co - corpuscles; cs - cirrus-sac; gp - genital pore; mg - Mehlis' gland; oc - osmoregulatory canal; ov - ovary; $\mathrm{t}$ - testes; us - uterine sac; va - vagina; vf - vitelline follicles.

mature segment $(n=20)$; its proximal part surrounded by numerous gland cells (Fig. 26). External sperm duct narrow, tightly coiled; internal sperm duct coiled; cirrus massive, armed with large spines about 3 long (Fig. 25).

Genital atrium small, dorsal and sublateral, 9001,170 from lateral margins, pre-equatorial to postequatorial (at 25-67\% of segment length). Ovary bilobed, follicular, posteromedian to cirrus-sac, 105-230 long by $475-1,220$ wide $(n=15)$; isthmus very narrow and long (Fig. 26). Vagina tubular, thin-walled, crossing ovary dorsally, then angled laterally, with proximal part 22-35 in diameter $(\mathrm{n}=10)$, and thick-walled markedly distended distal part, 35-60 in diameter; surrounded by large ring-like sphincter, 110-170 in diameter in median 
part of atrium (Fig. 26). Vitelline follicles numerous, large $(42-70$ in diameter; $n=20)$, cortical and medullary along ventral layer of inner longitudinal musculature; vitelline follicles continuous between segments (Fig. 24).

Uterine duct winding, forming numerous thin-walled loops, filled with eggs and enlarged in gravid segments (Fig. 24). Uterine sac oval, submedian, occupying anterior part of segment (Fig. 24). Uterine pore thickwalled, submedian and ventral, near anterior margin of segment. Eggs oval, operculate, unembryonated, surface slightly pitted, 53-66 long by $35-40$ wide $(\mathrm{n}=20)$ (Fig. $10)$.

Type and only host: Centrolophus niger.

$\mathrm{S}$ i t e of i n f e t i o $\mathrm{n}$ : Scolex in pyloric caeca, strobila rolled in the intestine.

$\mathrm{T}$ y p e 1 o c a 1 i t y : Ligurian Sea off Genoa, Italy (Mediterranean Sea).

D i s t r i b u t i o n : Atlantic Ocean (Outer Hebrides, Azores Islands, France, South Africa); Mediterranean Sea (Venice, Padua, Naples); North Sea (Scotland); Pacific Ocean (New Zealand).

Remarks. Monticelli (1890) described Bothriocephalus wageneri from Centrolophus pompilius (now C. niger). Ariola (1895) transferred it to Diplogonoporus Lönnberg, 1892, because of the presence of double sets of genital complexes per segment. Schumacher (1914) established a new genus, Echinophallus, and a new family, Echinophallidae, to accommodate this species.

In 1935, Guiart proposed a new genus for his new species, Atelemerus acanthoides, and differentiated it from Echinophallus only on the basis of the presence of "spines" (in fact large spiniform microtriches) on the posterolateral margins of pseudosegments (supposed to be absent in Echinophallus). Bray et al. (1994) synonymised Atelemerus with Echinophallus which also possesses these microtriches, but they did not formally synonymise $A$. acanthoides with $E$. wageneri. These species are considered to be conspecific herein.

Diplogonoporus settii Ariola, 1895 is also synonymised with E. wageneri. Ariola (1900b) distinguished the species mainly on the basis of the size of the strobila $(40 \mathrm{~cm} \times 0.81 \mathrm{~cm}$ in $D$. setti versus $15 \mathrm{~cm} \times$ $0.11 \mathrm{~cm}$ in E. wageneri). However, this character is not suitable for differentiation of echinophallid cestodes, because it depends on the host size, intensity of infection and other factors, and may vary considerably within species, as observed also in this study.

The present study has revealed only a few discrepancies between the original description of E. wageneri, subsequent morphological accounts and our data. Echinophallus wageneri was reported to possess a pseudoscolex (Yamaguti 1959, Schmidt 1986, Bray et al. 1994), but the anterior part of the body is considered herein to be a true scolex (Fig. 6), as claimed by
Schumacher (1914) and Protasova (1977). Some authors (Schumacher 1914, Protasova 1977) reported unoperculate eggs in Echinophallus, but the eggs were found to possess a feebly developed, but distinct operculum, as observed using SEM (Fig. 10).

\section{Milanella familiaris Kuchta et Scholz, 2008}

Amphicotyle heteropleura (Diesing, 1850) of Bray et al. (1994) in part; A. heteropleura of Brabec et al. (2006).

Milanella familiaris (Bothriocephalidea: Triaenophoridae) has been described recently by Kuchta and Scholz (2008). It is characterized by combination of the following characteristics: (i) trapeziform, markedly craspedote segments with a velum-like posterior margin and horn-like lateral projections; (ii) a pyriform uterine sac in the first gravid segments; (iii) arrow-shaped scolex with a well-developed apical disc and prominent posterior margins; (iv) the strobila containing intensely stained corpuscles most numerous in its anterior part; (v) a deeply lobated ovary; (vi) absence of a neck; (vii) a large, pyriform, thin-walled cirrus-sac with the proximal part bent anteromedially; (viii) the vagina posterior to the cirrus-sac; (ix) cortical vitelline follicles; and (x) unoperculate, unembryonated eggs (Kuchta and Scholz 2008)

Type and only host: Centrolophus niger.

$\mathrm{S}$ i t e of infection: Scolex attached to pyloric caeca, strobila in the anterior part of the intestine.

T y p e 1 o c a lity: North Atlantic west off Outer Hebrides.

Remarks. Data on the morphology of the species are provided by Kuchta and Scholz (2008).

In order to facilitate identification of bothriocephalidean cestodes found in the blackfish, a simple key based on gross morphology is provided.

\section{Key to the cestodes of Centrolophus niger}

1 Strobila very wide (width $>5 \mathrm{~mm}$ ); double genital complexes per segment ..... Echinophallus wageneri

- Strobila narrower (width $<5 \mathrm{~mm}$ ); single genital complex per segment 2

2 Strobila folded along longitudinal axis, spiralled throughout its length; scolex oval, with nipple-like posterior projection; genital pore sublateral

\section{Bothriocotyle solinosomum}

- Strobila straight, never rolled or spiralled; scolex without posterior nipple-like projection; genital pore marginal

3 Segments much wider than long; bothria with posterior sucker-like depression

Amphicotyle heteropleura

- Segments trapeziform; bothria without posterior sucker-like depression Milanella familiaris 

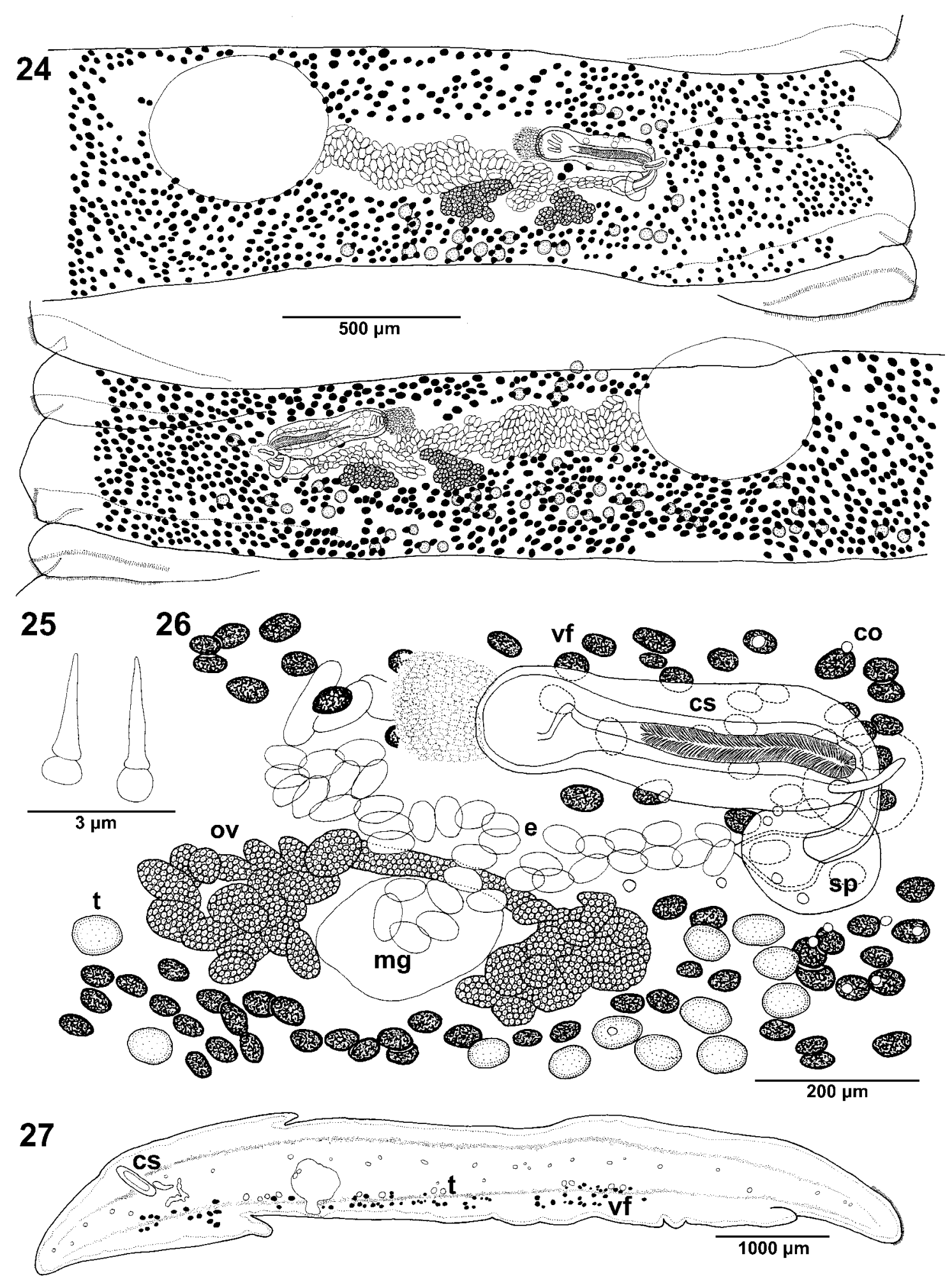

Figs. 24-27. Echinophallus wageneri from Outer Hebrides. Fig. 24. Gravid segment; dorsal view; eggs in uterine sac not illustrated. Fig. 25. Detail of cirrus spines. Fig. 26. Terminal genitalia; ventral view. Fig. 27. Cross-section of segment at the level of cirrus-sac. Abbreviations: co - corpuscles; cs - cirrus-sac; e - eggs; mg - Mehlis' gland; ov - ovary; $\mathrm{sp}$ - sphincter; $\mathrm{t}$ - testes; $\mathrm{vf}-$ vitelline follicles. 


\section{DISCUSSION}

Bothriocephalidean tapeworms are quite common parasites of marine teleosts and many of them occur in deep-sea fishes (Campbell 1983, Bray et al. 1994, Klimpel et al. 2001, Kuchta and Scholz 2007, Kuchta et al. 2008). Numerous taxa have strict host specificity and usually only one cestode species occurs in one host taxon (Kuchta and Scholz 2007). Centrolophus niger, along with other centrolophid fishes (Kuchta and Scholz 2007), represents an exception, because it hosts as many as four bothriocephalidean tapeworms of four different genera.

Centrolophus niger is a bathypelagic fish, living offshore in temperate waters of all oceans in depth range of 40-1,050 m. Juveniles occur in surface waters, but adults live deeper. Blackfish feed on whatever is available, including small fish, squids and large pelagic crustaceans (see Froese and Pauly 2008 for references).

Only nine blackfish were examined in the present study (specimens from Italy and New Zealand are included), which does not enable us to provide reliable data on the rate of infection with bothriocephalidean cestodes. Nevertheless, it seems that the prevalence of infection may be fairly high and that several cestode species may simultaneously infect the same fish host.

Seven blackfish caught in deeper waters of the Atlantic, Pacific and Mediterranean Sea were heavily infected with cestodes of at least three species, namely Amphicotyle heteropleura, Bothriocotyle solinosomum and Echinophallus wageneri. The intestines of these fish were filled with tapeworms, including small worms corresponding to plerocercoids or unidentifiable juveniles. Therefore, it is possible that some of these worms may have belonged to the fourth species, Milanella familiaris. The intensity of infection of these nine fish with mature, identifiable tapeworms ranged between 1 to 18 specimens in A. heteropleura, 2 to 26 in B. solinosomum and 1 to 18 in E. wageneri. On the contrary, another two blackfish caught at the depth of $1,000 \mathrm{~m}$ from North Atlantic west off Outer Hebrides were infected exclusively with $M$. familiaris (see Kuchta and Scholz 2008).

Tapeworms occurring in the blackfish belong to two bothriocephalidean families, Triaenophoridae and Echinophallidae. In the blackfish, two triaenophorids have been found, namely A. heteropleura and M. familiaris. Amphicotyle is considered to be monotypic (Kuchta and Scholz 2007), although several taxa were previously placed in this genus. Amphicotyle ceratias Tkachev, 1979 from Ceratias holboelli Krøyer will be transferred to a new genus (Kuchta et al., in preparation), whereas Amphicotyle kurochkini Tkachev, 1979 from Seriolella sp. is in fact a member of Glossobothrium (see Kuchta and Scholz 2007).

Milanella has been proposed just recently to accommodate a new species, $M$. familiaris, found in the blackfish from the North Atlantic west off Outer Hebrides
(Kuchta and Scholz 2008). Milanella is monotypic and most closely resembles Bathycestus Kuchta et Scholz, 2004, Pistana Campbell et Gartner, 1982 and Probothriocephalus Campbell, 1979. It differs mainly in the shape of segments (trapeziform, markedly craspedote, with a velum-like posterior margin and horn-like lateral projections) and uterine sac (pyriform in the first gravid segments - see Kuchta and Scholz 2008).

Another two bothriocephalidean cestodes found in the blackfish, E. wageneri and B. solinosomum, belong to the Echinophallidae. This is a small, little-studied group of exclusively marine tapeworms (Bray et al. 1994). Both taxa found in Centrolophus possess the features that may represent synapomorphies of the family, i.e. a sublateral genital pore, the cirrus armed with spines (Levron et al. 2008), and posterolateral margins of segments lined with a band of large spiniform microtriches (Bray et al. 1994, Kuchta 2007). However, the monophyly of the Echinophallidae has not been confirmed by molecular data (Brabec et al. 2006).

Bothriocotyle solinosomum can be easily distinguished from all other bothriocephalidean cestodes from the blackfish by the shape of its strobila (folded and spiralled), whereas E. wageneri is typified by a markedly large strobila. Echinophallus is currently composed of five valid species (see Kuchta and Scholz 2007), namely E. wageneri (Monticelli, 1890) (type species) from C. niger; E. lonchinobothrium (Monticelli, 1890) from Coryphaena hippurus L., described as Bothriocephalus lonchinobothrium; E. peltocephalus (Monticelli, 1893) from Schedophilus ovalis (Cuvier), described as Bothriocephalus peltocephalus; E. seriolellae Korotaeva, 1975 from Seriolella brama (Günther); and E. stossichi (Ariola, 1896) from Trachipterus trachypterus (Gmelin), described as Bothriocephalus stossichi.

The eggs of the three cestode species redescribed in this paper were studied using SEM for the first time and were found to be operculate. The operculum is in all three taxa feebly developed and this may be the reason why it is almost indistinguishable when intrauterine eggs are observed in mounted preparations using light microscopy. Previously, an operculum had never been described in Amphicotyle and Bothriocotyle. Yamaguti (1934) described an operculum in the eggs of Echinophallus japonicus Yamaguti, 1934 and later (Yamaguti 1959) reported the eggs to be operculate in the generic diagnosis of Echinophallus. However, the author did not observe the eggs of E. wageneri, but those of E. japonicus, a species which was later transferred to Paraechinophallus by Protasova (1975).

SEM observations of the eggs have also revealed that their surface is not smooth. In A. heteropleura, the eggs have rugose structure, whereas those of $B$. solinosomum and E. wageneri are pitted. Similar structures were observed by Hilliard (1972) in the eggs of diphyllobothriid cestodes. 
Acknowledgements. The authors are grateful to A.P. Shinn, Institute of Aquaculture, University of Stirling, UK, for possibility to collect material in North Atlantic on the research vessel Scotia (supported by the Access to Research Infrastructure Action of the Improving Human Potential Programme of the European Community; contract HPRI-CT-2001-00180), to M. Borovková for providing technical assistance, M. Tesařová for electron microscopical studies and to R.A. Bray, H.H. Williams and C. Healy (supported by the National Institute of Water \& Atmospheric Research of New Zealand and funding from an NSF PEET grant DEB 0118882 to Janine Caira and Timothy Ruhnke) for providing material. This study was partially supported by the Grant Agency of the Czech Republic (projects Nos. 524/03/H133 and 524/04/0342), Institute of Parasitology (projects Z60220518 and LC522), and Faculty of Science, University of South Bohemia (MSM 6007665801). Stays of the first author in The Natural History Museum in London and Muséum National d'Histoire Naturelle in Paris were supported by the SYNTHESYS programme of the European Union (project Nos. GB-TAF-735 and FR-TAF-3975). R.K. and T.S. thank J. Mariaux and A. de Chambrier, Muséum d'Histoire Naturelle in Geneva, Switzerland, for support during their research stays in Geneva.

\section{REFERENCES}

ARIOLA V. 1895: Due nuove specie di Botriocefali. Atti Soc. Ligust. Sci. Nat. Geogr. 6: 247-254.

ARIOLA V. 1900a: Nota sui Cestodi parassiti del Centrolophus pompilius Linn. Boll. Mus. Zool. Anat. Comp. R. Univ. Genova 93: 1-6.

ARIOLA V. 1900b: Revisione della famiglia Bothriocephalidae. Arch. Parasitol. 3: 369-484.

Brabec J., Kuchta R., SchOlZ T. 2006: Paraphyly of the Pseudophyllidea (Platyhelminthes: Cestoda): circumscription of monophyletic clades based on phylogenetic analysis of ribosomal RNA. Int. J. Parasitol. 36: 1535-1541.

BRAY R.A., JONES A., ANDERSEN K.I. 1994: Order Pseudophyllidea Carus, 1863. In: L.F. Khalil, A. Jones and R.A. Bray (Eds.), Keys to the Cestode Parasites of Vertebrates. CAB International, Wallingford, UK, pp. 205-247.

CAMPBELl R.A. 1983: Parasitism in the deep sea. In: G.T. Rowe (Ed.), The Sea. Vol. 8. Harvard University Press, Cambridge, Massachussets, New York, London, pp. 473-552.

DIESING K.M. 1850: Systema Helminthum. Volume I. Apud Wilhelmum Braumüller, Vindobonae, 679 pp.

DIESING K.M. 1863: Revision der Cephalocotyleen. Abteilung 1. Paramecocotyleen. Sitzungsber. Akad. Wiss. Wien Math.Naturwiss. Klasse 48: 200-345.

Froese R., PAUly D. (Eds.) 2008: FishBase. World Wide Web electronic publication, http://www.fishbase.org, version $01 / 2008$.

GUIART J. 1935: Cestodes parasites provenant des campagnes scientifiques de S.A.S. le Prince Albert Ier de Monaco (18861913). Résultats des Campagnes Scientifiques du Albert Ier, Prince de Monaco 91: 1-105.

HILLIARD D.K. 1960: Studies on the helminth fauna of Alaska. LI. Observations on eggshell formation in some diphyllobothriid cestodes. Can. J. Zool. 50: 585-592.

Klimpel S., Seehagen A., Palm H.-W., Rosenthal H. 2001: Deep-Water Metazoan Fish Parasites of the World. Logos Verlag, Berlin, Germany, 316 pp.

KUCHTA R. 2007: Revision of the paraphyletic "Pseudophyllidea" (Eucestoda) with description of two new orders Bothriocephalidea and Diphyllobothriidea. PhD thesis, Faculty of Biological Sciences, University of South Bohemia, České Budějovice, Czech Republic, $97 \mathrm{pp}$.

KuChTA R., SchOlZ T. 2007: Diversity and distribution of fish tapeworms of the "Bothriocephalidea" (Eucestoda). Parassitologia 49: 21-38.
KUCHTA R., SCHOLZ T. 2008: A new triaenophorid tapeworm from blackfish Centrolophus niger. J. Parasitol. 94: 500-504.

Kuchta R., SCHOLZ T., BRABEC J., BRAY R.A. 2008: Suppression of the tapeworm order Pseudophyllidea (Platyhelminthes: Eucestoda) and the proposal of two new orders, Bothriocephalidea and Diphyllobothriidea. Int. J. Parasitol. 38: 4955.

Levron C., Poddubnaya L.G., Kuchta R., Freeman M., WANG Y.-H., SCHOLZ T. 2008: First SEM and TEM study of the armed male terminal genitalia of the tapeworm Paraechinophallus japonicus (Cestoda: Bothriocephalidea). J. Parasitol. (In press.)

LÜHE M. 1902: Bemerkungen ueber die Cestoden aus Centrolophus pompilius. I. Zur Synonymie der Centrolophus-Cestoden. Zentralbl. Bakteriol. 31: 629-637.

MONTICELli F.S. 1890: Note elmintologiche. Boll. Soc. Nat. Napoli 4: 189-208.

PROTASOVA E.N. 1975: [Paraechinophallus nov. gen. (Pseudophyllidea) from marine fish Psenopsis anomala]. Trudy GELAN 25: 109-115. (In Russian.)

PROTASOVA E.N. 1977: [Bothriocephalata - Tapeworm Helminths of Fish.] Principles of Cestodology. K.M. Ryzhikov (Ed.). Volume 8. Nauka, Moscow, 298 pp. (In Russian.)

SCHMIDT G.D. 1986: CRC Handbook of Tapeworm Identification. CRC Press, Boca Raton, Florida, USA, 675 pp.

SCHOLZ T., DRÁBEK R., HANZELOVÁ V. 1998: Scolex morphology of Proteocephalus tapeworms (Cestoda: Proteocephalidae), parasites of freshwater fish in the Palaearctic Region. Folia Parasitol. 45: 27-43.

SCHOLZ T., HANZELOVÁ V. 1998: Tapeworms of the Genus Proteocephalus Weinland, 1858 (Cestoda: Proteocephalidae), Parasites of Fishes in Europe. Studie AV ČR, No. 2/98, Academia, Praha, 119 pp.

SCHUMACHER G. 1914: Cestoden aus Centrolophus pompilus (L.). Zool. Jahrb. Syst. 36: 149-198.

WAGENER G.R. 1854: Die Entwicklung der Cestoden nach eigenen Untersuchungen, Verhandl. Kaiserl. Leopold Carol. Akad. Naturforscher Nova Acta Akad. Naturwiss. Curios, 22 (Suppl.), 112 pp.

YAMAGUTI S. 1934: Studies on the fauna of Japan IV. Cestodes of fishes. Jpn. J. Zool. 6: 1-112.

YAMAGUTI S. 1959: Systema Helminthum, Vol. II. The Cestodes of Vertebrates. Keigaku Publishing House, Tokyo, Japan, 860 pp. 